\title{
English Passive Alternation by Saudi EFL Students
}

\author{
Reem A. Alotaibi ${ }^{1}$ \\ ${ }^{1}$ Department of English Language \& Literature, College of Arts, King Saud University, Riyadh, Saudi Arabia \\ Correspondence: Reem A. Alotaibi, P. O. Box 642, Riyadh 11421, Saudi Arabia. E-mail: \\ reemahmad2063@gmail.com
}

Received: September 10, 2018

Accepted: October 9, 2018 Online Published: December 29, 2018

doi:10.5539/ijel.v9n1p343

URL: https://doi.org/10.5539/ijel.v9n1p343

\begin{abstract}
This study examines Saudi Arabian EFL students in relation to alternating, and non-alternating passive verbs. This study also considers factors related to the mastering of alternating / non-alternating verbs by (40) Saudi student participants related to correct/incorrect usage of alternating / non-alternating verbs by Saudi Arabian EFL student participants in a Grammaticality Judgment Task (GJT). The results of this study demonstrate that participants scored a satisfactory mean score of correct answers in the usage of alternating verbs $(79 \%)$. On the other hand, this study demonstrates that the (40) Saudi EFL student participants achieved a total mean score of (48\%) for non-alternation verbs. This study then considers possible causes for correct usage of alternating verbs and proposes to identify elements which relate to correct transfer by the (40) Saudi EFL student participants. In conclusion, this study demonstrates that the over-generalizing of the passivisation rule for verbs that do not alternate resulted in improper usage. Lastly, this study indicates that a similarity between the construction of the non-causative and passive construction gives rise to improper understanding of English Passive Alternation by Saudi EFL student participants.
\end{abstract}

Keywords: learnability problem, passive alternation, Saudi EFL learners, second language acquisition

\section{Introduction}

The use of passive alternation has been the subject of many studies focusing on the acquisition constraints (i.e., Pinker, Lebeaux, \& Frost, 1987; Thatcher, Branigan, McLean, \& Sorace, 2007). Researchers have focused on investigating the constraints encountered by both young learners and adult learners when mastering the usage of passive alternation (e.g. age; actional verbs vs. non-actional verbs; and active vs. early comprehension of the passive). Pinker (1989,) asserted that as with the other lexico-syntactic alternations (i.e., locative, dative, and causative alternations) passive alternation poses a problem for both young learners and adult learners. Pinker concluded that proper usage of the alternating verb is due to structures that allow certain verbs to alternate.

Pinker founded his research on the premise that a number of steps are needed to form a passive voice. As an example of this is the verb saw in the sentence (John saw Sara). John is the first argument working as the subject, and Sara is the second argument working as the direct object. The sentence can be changed into passive voice as follows (Sara was seen by John), in which the verb has been affected by adding the auxiliary be (was). In addition, the verb has been changed into a participle (seen) affecting its morph-syntactic category (Alotaibi \& Alajmi, 2015). The subject of the sentence now becomes Sara rather than John. Moreover, Pinker (1989) observed that the verbs most likely to be passivized are actional when the patient of the sentence (object) is affected (Alotaibi \& Alajmi, 2015). Gordon \& Chafetz (1990) supported Pinker's (1989) claim. The results indicated that young learners succeed in comprehending actional verb passives earlier than non- actional verb passives. None-the-less, other research Haegeman (1991) indicates that stative verbs cannot be passivized, as in the example: Five is equaled by three plus two (Alotaibi \& Alajmi, 2015).

Collateral research completed by Alotaibi and Alajmi (2015), proposes that in order for the verb to be passivized the argument subject within the sentence has to be of great status compared to the object proceeded with the preposition by according to the Thematic Hierarchy Condition (Jackendoff, 1972). For example, the verb stolen in the sentence the money was stolen by the robber is passivized due to the subject (the money) being of high position. The sentence is not fundamentally changed if the object is deleted (by the robber), since the main argument of the sentence can still be seen.

In relation to this, Jackendoff (1972) noted that, in order to be passivized, a sentence tends to have the following 
arranged thematic relations: Theme, source/goal/location, and agent. However, certain verbs (i.e., escape) refute this ordered relationship and thus cannot be passivized. In the example Mike escaped from Pop, the verb escape demonstrates that Pop acts as a source during transference into passive voice. This contradicts the thematic relations order (i.e., theme), and it cannot therefore be passivized/ alternated (Alotaibi \& Alajmi, 2015).

The above research leads to the conclusion that not all verbs passivize or alternate which can cause issues for EFL learners when constructing the English passive alternation with the conclusion being that insufficient attention has been given to EFL learners' acquisition of the four lexico- syntactic alternations, specifically the passive

In relation to the above premise that research lacks in the area of the four lexico- syntactic alternations by EFL students, this study seeks to expound upon the issues: (1) Into what amount Saudi EFL students obtain the ability in differentiating alternating and non-alternating passive verbs? (2) What are the factors related to the causes for proper usage of English Passive Alternation by Saudi EFL student research participants?

\section{Literature Review}

\subsection{Overview}

Lexico-syntactic alternation types (i.e., passive, causative, locative, and dative), as outlined by Pinker (1989), received little attention in relation to EFL learners' acquisition of language. These alternation types all have issues of learnability, which, as suggested by Pinker (1989), is similar to the well-known Baker's paradox learnability problem (Alotaibi \& Alajmi, 2015). An alternation can be described as "a change in the linguistic realization of the argument structure of a verb with respect to a postulated base form" (Moriceau \& Saint-Dizier, 2003, p. 1).

Among the studies investigating Arab EFL learners' acquisition of the lexico-syntactic types is that of Alotaibi and Alajmi (2015) who examined fifty EFL Kuwaiti students' ability in distinguishing between passivized and non-passivized verbs. They employed a (GJT) questionnaire, the same instrument adopted for this current research. Alotaibi and Alajmi (2015) believed their participants were qualified to take part in their study due to being advanced learners, who had studied the English language for a period of twelve years at Kuwaiti public schools. The mean age of the participants was twenty-two. The results indicated that the learners performed well with regard to verbs that passivize, possibly due to a positive transfer from their L1, i.e., Kuwaiti Spoken Arabic. In addition, Alotaibi and Alajmi (2015) also found that the participants faced a number of difficulties when it came to verbs that do not passivize.

The reasons for such errors could be overgeneralization of the passivisation rule, while the participants' confusion between the construction of the non-causative and the passive may also played a role in marking non-alternating verbs as being grammatically correct. Both constructions do not necessarily take an object. This led Alotaibi and Alajmi (2015) to conclude that the fifty advanced Kuwaiti EFL learners (who had achieved a score of $45 \%$ ) had not mastered the English passive.

Zibin and Altakhaineh's (2016) study focused on four lexico- syntactic alternations, to investigate the acquisition of the English causative alternation by eighty Jordanian English Language students, who were in their fourth year of a BA course. Zibin and Altakhaineh (2016) noted that a causative verb can function in two structures, and that a number of semantically- based conditions are required for a verb to be causativize, as outlined by Pinker (1989, p. 130). Zibin and Altakhaineh (2016) used GJT to examine the participants' performance. The findings suggested that the major differences between the semantically-based constraints in administering the causative alternation in English and in Jordanian Arabic caused the participants to struggle to acquire the causative alternation.

Locative alternation has received little attention in relation to EFL learners. Alotaibi (2015) examined the ability of one hundred Kuwaiti EFL learners to distinguish between alternating and non-alternating verbs in regard to the English locative type. Locative alternation transfers a substance (i.e., the content or theme) into a container, i.e., the goal or location (Pinker, 1989, p. 49). The study indicated that the positive performance of the participants was identified by means of verbs that tend to alternate, in contrast to those that do not. A negative transfer of the argument structure of verbs from the participants' L1 into English influenced the participants' ability to mark non-alternating locative verbs in a grammatically correct manner.

\subsection{Passive Alternation}

Many studies, including those of Pinker et al. (1987) and Thatcher et al. (2007), of the English passive alternation have concentrated primarily on children's acquisition of challenging constructions, i.e., the English passive verb. Pinker et al. (1987) conducted a number of experiments on children, each of which differed in the 
number, and age, of the participants. The study revealed that children are not conservative in generating passives for those verbs they have heard to be passivized in their input. The study demonstrated that children experienced no constraints in passivizing non- actional verbs.

Furthermore, the study of Thatcher et al. (2007) on the use of the English passive verb by children aimed to contradict the claims of previous studies that children over five are more adept at mastering actional verb passives than non-actional verbs. Thatcher et al. (2007) therefore examined the early acquisition of the passive by twenty children aged between three and four by means of: (1) syntactic priming tasks; (2) prime structure (active vs. passive); and (3) verb type (actional vs. non-actional). The results revealed that children aged between three and four had the ability to produce a passive construction following passive primes, rather than active primes. The results also contradicted the literature stating that the acquisition of the English passive is semantically constrained, as children under the age of five succeeded in comprehending the passive rule and were able to generalize the rule equally to actional and non-actional verbs.

A number of other researchers into the use of the English passive verb have shed light on the impact of EFL learners' L1 on the acquisition of L2. Izumi and Lakshmanan (1998) examined the ability of fifteen adult Japanese ESL learners to acquire the English passive verb, due to this posing a learnability problem as a result of the differences between the structures of the two languages, i.e., Japanese has both the direct and indirect passive, but English has only the direct passive. The researchers gave all participants a pretest of the English passive, subsequently dividing them into two groups, as follows: (1) an experimental group and (2) a control group. The experimental group was instructed on the English passive construction by native Japanese speakers, while the control group received no instruction. Following this, both groups undertook a posttest, with the experiment group demonstrating a significant improvement in mastering the passive verb in comparison to the control group. This emphasizes the influence of the L1 over the control group, i.e., participants who had received no instruction.

\section{Methodology}

\subsection{Sample}

The participants of the current study consisted of forty BA female students studying English Language and Literature at King Saud University, in Saudi Arabia, who were in the early stages of their BA course, i.e., levels 2 and 3. The participants had previously enrolled in an intensive English language course over one semester (i.e., during their preparatory year), resulting in six hours of credit. All participants had also studied the English language at public schools in Saudi Arabia for six years prior to applying to university. The participants were all native speakers of Saudi Spoken Arabic (SSA), and their ages ranged between nineteen and twenty-one.

\subsection{Data Collection}

The current researcher adopted Alotaibi and Alajmi's (2015) GJT questionnaire. The GJT instrument has been adopted for many studies to investigate other lexico-syntactic alternations (i.e., Mazurkerwich, 1984; Choi \& Lakshmanan, 2002; Alotaibi, 2015; Zibin \& Altakhaineh, 2016). The GJT consisted of twenty-one items: ten verbs that alternated (passivize), a further ten that did not alternate (not passivized), and an inchoative verb used ungrammatically to distract participants when distinguishing between alternating and non-alternating verbs. The tool required participants to mark sentences that were grammatically proper to them with a tick, and those that appeared to be improper to them with a across (Check Appendix A).

It should be noted that Alotaibi and Alajmi (2015) found that the selected verbs in the test were of common use. Since these verbs are commonly used in contemporary speech, the Saudi participants of this study (who majored in the English Language and were exposed to the language from the age of thirteen) tended to understand the meanings of the verbs selected in the GJT. Check Appendix A for the GJT test.

The verbs chosen for the test are as follows:

1) Ten non-passivation verbs (i.e., tend not to alternate):

'Lack; resemble; equal; escape; weigh; cost; sleep; arrive; belong; and marry'

2) Ten passivation verbs (i.e., tend to alternate):

'Beat; build; made; complete; eat; protect; smash; steal; paint; and lose'

3) Ungrammatical verb used as a distracter:

'Disappear' 


\section{Results and Discussion}

This study investigated to what extent 40 Saudi EFL learners have acquired the alternating and non-alternating passive verbs? And what are the potential causes of correct/incorrect answers provided by participants? The results revealed that participants were particularly successful in the use of verbs that alternate (passivize), while they encountered difficulties with verbs that do not passivize, i.e., they considered the following example of a stative verb as being grammatically correct: Nine is equaled by five plus four.

Table 1 (below) shows the correct answers (out of 40) and their percentages in relation to alternating verbs.

Table 1. Number of correct answers and their percentages for verbs that passivize in the GJT:

\begin{tabular}{lll}
\hline Alternating verbs & Number of correct answers & Percentage of correct answers \\
\hline Beat & 37 & $92 \%$ \\
Build & 36 & $90 \%$ \\
Made & 33 & $82 \%$ \\
Complete & 32 & $80 \%$ \\
Eat & 31 & $77 \%$ \\
Protect & 28 & $70 \%$ \\
Smash & 29 & $72 \%$ \\
Steal & 30 & $75 \%$ \\
Paint & 31 & $77 \%$ \\
Lose & 30 & $75 \%$ \\
Total mean & 31 & $79 \%$ \\
\hline
\end{tabular}

Table 1 demonstrates that the participants had an adequate acquisition of the passive alternation concerning verbs that alternate, scoring a total mean of $79 \%$. The highest percentage was seen in relation to the verb beat $(92 \%)$, i.e., thirty-seven out of forty participants gave the correct answer. The verbs that scored the lowest were protect, and smash, being $70 \%$ and $72 \%$, respectively.

The verb beat $(92 \%)$ achieved the highest degree of correct answers, potentially due to a positive transfer of participants' L1, i.e., the participants may have transferred their L1 structure to the English language. Check Appendix B for Arabic sounds.

1-arjantin n-hazmat

Argentina was beaten

Further verbs with a high number of correct answers were build (90\%) and steal (75\%). Here too, a positive transfer from participants' L1 played a role in these verbs being passivized, thus enabling the participants to give correct answers, i.e., the structure of the verbs build and steal in L1 was similar to the structure of L2, as seen below:

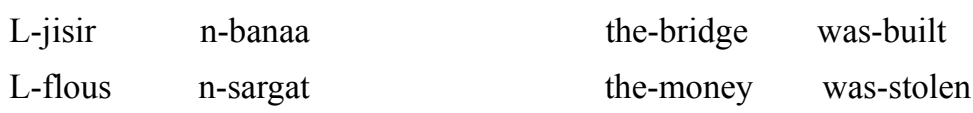

In Saudi spoken Arabic, the prefix n- is added to form a passive verb.

This result is consistent with that of Alotaibi and Alajmi (2015) and Alotaibi's (2015) findings. They found that a positive transfer from L1 to L2 was a factor for participants' correct answers.

A further factor in participants' ability to give correct answers for alternating verbs is the familiarity of these verbs. Verbs such as made (82\%), lose (75\%) and complete $(80 \%)$ are not passivized in the participants' L1, however, they may be frequently used by participants, or participants have been exposed to them during their study of English subjects, i.e., grammar, writing, listening and speaking. These English courses take place during the early stages of a BA course and generally focus on those aspects learners may find difficult, i.e., the passive vs. the active voice. Mastering such constructions can help learners proceed to the next levels, where literature and linguistic courses play an essential role in the curriculum.

The verbs with the lowest scores were smash (72\%) and protect (70\%). Participants may have encountered difficulties in understanding the meaning of words such as smash, and thus preferred to mark the sentence as being grammatically incorrect. In addition, participants may not have previously come across the passive form of the verb protect. Thus, a lack of familiarity may prove a factor in the verbs protect and smash being marked as grammatically incorrect, either in regard to meaning or participants' input of the construction of passive sentences. 
Table 2 (below) shows the number of correct answers (out of 40) in relation to non-alternating verbs and their percentages.

Table 2. Number of correct answers concerning verbs that do not passivize in GJT

\begin{tabular}{lll}
\hline Non-alternating verbs & Number of correct answers & Percentage of correct answers \\
\hline Lack & 14 & $35 \%$ \\
Resemble & 16 & $40 \%$ \\
Equal & 13 & $32 \%$ \\
Escape & 15 & $37 \%$ \\
Weigh & 16 & $40 \%$ \\
Cost & 26 & $65 \%$ \\
Sleep & 29 & $72 \%$ \\
Arrive & 18 & $45 \%$ \\
Belong & 29 & $72 \%$ \\
Marry & 19 & $47 \%$ \\
Total mean & 19 & $48 \%$ \\
\hline
\end{tabular}

Table 2 reveals that participants did not acquire the English passive with regard to non-alternating verbs with the total mean of $48 \%$. This result is consistent with that of (Zibin \& Altakhaineh, 2016; Alotaibi \& Alajmi, 2015; Alotaibi, 2015) who investigated the acquisition of the lexico-syntactic alternation types. They all found that their participants struggled with non-alternating verbs and thus scored low mean scores of correct answers.

The highest scores were seen with the verbs sleep (72\%), and belong (72\%), with the participants able to master the passive forms of these verbs with ease. The lowest scores were found in relation to verbs such as lack (35\%), equal (32\%), and resemble (40\%).

The verbs sleep and belong (which received the highest number of correct answers out of the non-alternating verbs) are intransitive, i.e., in contrast to transitive verbs, these cannot be passivized. Thus, the participants demonstrated good knowledge of the passivisation rule. However, they began to over-generalize the rule on transitive verbs that cannot necessarily be passivized. Examples of these verbs are lack (35\%), and resemble $(40 \%)$, which scored a low number of correct answers due to an over-generalization of the passivisation rule.

On the other hand, the verb equal, is considered a stative verb, one that Haegeman (1991) stated cannot be passivized. However, the GJT test found that the verb equal scored the lowest number of correct answers (32\%), possibly due to an over-generalization of the passive rule. Participants also emphasized generalizing the passive rule over stative verbs, as seen in the low score result related to the verb weigh $(40 \%)$.

The verbs escape (37\%) and arrive (45\%) scored also a low number of correct answers. The poor performance of participants in relation to the verb arrive could be attributed to their confusion between the construction of non-causative verbs (the singers arrived yesterday) and the passive, as both do not take an object. This result is consistent with that of Alotaibi and Alajmi (2015). When it comes to the verb escape, participants may have marked it as grammatically correct simply due to an ability to see clearly the subject and object of the sentence.

\section{Conclusion and Recommendation}

This study focused on the extent to which Saudi EFL learners understand English structure alternating and non-alternating passive verbs? This study then goes on to analyze the potential causes of correct/incorrect usage of the English Passive Alternation by Saudi EFL student participants? Research results indicate that Saudi EFL student participants performed well in regards to alternating verbs $(79 \%)$, while lacking skills $(48 \%)$ related to verbs that do not alternate.

This study therefore concludes that proper usage concerning alternating verbs may be the result of a positive transfer from L1 to L2. This study indicates that a familiarity with verbs that alternate may have led participants to mark them as grammatically correct. This study indicates that non-alternating verbs gave rise to an over-generalization of the passive rule which gave rise to improper usage of English Passive Alternation. It is proposed that the similarity of the non-causative verb structure and passive construction results in improper usage by Saudi EFL student participants. As a result, our research indicates that a lack of research into the four lexico-syntactic alternations that give rise to issues for Saudi EFL students. 


\section{References}

Alotaibi, A. (2015). The Acquisition of the English Locative Alternation by Kuwaiti EFL Learners. International Journal of Applied Linguistics and English Literature, 5(1).

Alotaibi, A., \& Alajmi, H. (2015). The Acquisition of the Passive Alternation by Kuwaiti EFL Learners. International Journal of English Linguistics, 5(1). https://doi.org/10.5539/ijel.v5n1p44

Choi, M. H., \& Lakshmanan, U. (2002). Holism and locative argument structure in Korean-English bilingual grammars. In B. Skarabela, S. Fish, \& A. H. J. Do (Eds.), Proceedings of the 26th annual Boston University conference on language development (pp. 95-106). Somerville, MA: Cascadilla Press.

Gordon, P., \& Chafetz, J. (1990). Verb-based versus class-based accounts of actionality effects in children's comprehension of passives. Cognition, 36(3), 227-254. https://doi.org/10.1016/0010-0277(90)90058-R

Haegeman, L. (1991). Introduction to government and binding theory. Oxford: Blackwell Publishers.

Izumi, S., \& Lakshmanan, U. (1998). Learnability, negative evidence and the L2 acquisition of the English passive. Second Language Research, 14(1), 62-101. https://doi.org/10.1191/026765898675700455

Jackendoff, R. (1972). Semantic interpretation in generative grammar. Cambridge: MIT Press.

Mazurkerwich, I. (1984). The Acquisition of the Dative Alternation by Second Language Learners and Linguistic Theory. Language Learning, 34, 91-108. https://doi.org/10.1111/j.1467-1770.1984.tb00997x

Moriceau, V., \& Saint-Dizier, P. (2003). Syntactic alternations at the confluence of syntax and semantics: the case of natural language generation. The Lorraine-Saarland Workshop Series: Prospects and Advances in the Syntax/Semantics $\quad$ Interface, $\quad$ Nancy. https://www.irit.fr/ Patrick.SaintDizier/publi_fichier/synsem.pdf

Pinker, S. (1989). Learnability and cognition: The acquisition of argument structure. Cambridge: MIT Press.

Pinker, S., Lebeaux, D., \& Frost, L. (1987). Productivity and constraints in the acquisition of the passive. Cognition, 26(3), 195-267. https://doi.org/10.1016/S0010-0277(87)80001-X

Thatcher, K., Branigan, H., McLean, J., \& Sorace, A. (2007). Children's early acquisition of the passive: evidence from syntactic priming. Child Language Seminar, University of Reading.

Zibin, A., \& Altakhaineh, A. (2016). Acquiring the English Causative Alternation: Evidence from the University of Jordan. International Journal of Applied Linguistics and English Literature, 5(3).

\section{Appendix A}

\section{The (GJT) Questionnaire}

After reading the sentences below. Mark sentences that appear to be grammatically proper to you with a tick, and those that appear to be grammatically improper to you with a cross:

1. The poor dolphin was eaten by the shark $\checkmark$

2. The baby is slept by his mother $X$

3. Argentina was beaten by Germany in the world cup $\checkmark$

4. Two dollars are cost by this pen $X$

5. Jennifer was married by Bill $X$

6. The tasks were completed by the student $\checkmark$

7. The bridge was built by 600 workers $\checkmark$

8. Nine is equalled by five plus four $X$

9. The singer is protected by her bodyguard $\checkmark$

10. Sue is resembled by her sister $X$

11. The thief disappeared the gold from the police $X$

12. The Mona Lisa was painted by Leonardo da Vinci $\checkmark$

13. The book is belonged by Sarah $X$

14. The money was stolen by the robber $\checkmark$ 
15. The singers were arrived yesterday $X$

16. The motivation was lacked by the players $X$

17. Four plates were smashed by Bill $\checkmark$

18. Her jewellery was lost in the airport $\checkmark$

19. Two hundred and twenty pounds is weighed by Sam $X$

20. The strawberry cake was made by Layla $\checkmark$

21 . The tiger was escaped by the hunter $X$

\section{Appendix B}

Below are the sounds of Arabic Language (Alotaibi \& Alajmi, 2015)

\begin{tabular}{|c|c|c|}
\hline Arabic consonants/vowels & Symbols & Description \\
\hline$s$ & $?$ & voiceless glottal stop \\
\hline 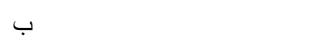 & $\mathrm{b}$ & voiced bilabial stop \\
\hline$ت$ & $\mathrm{t}$ & voiceless dento-alveolar stop \\
\hline$ث$ & $\theta$ & voiceless inter-dental fricative \\
\hline ج & $\mathrm{g}$ & voiced post-alveolar affricate \\
\hline$\tau$ & $\mathrm{h}$ & voiceless pharyngeal fricative \\
\hline$\dot{\tau}$ & $\mathrm{x}$ & voiceless uvular fricative \\
\hline 2 & $\mathrm{~d}$ & voiced dento-alveolar stop \\
\hline$\dot{j}$ & ð & voiced alveolar fricative \\
\hline s & $\mathrm{r}$ & voiced alveo-palatal trill \\
\hline j & $\mathrm{z}$ & voiced alveolar fricative \\
\hline س & $\mathrm{s}$ & voiceless alveolar fricative \\
\hline 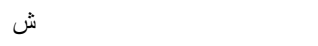 & $\int$ & voiceless alveo-palatal fricative \\
\hline ص & $\mathrm{s}$ & voiceless alveolar emphatic fricative \\
\hline 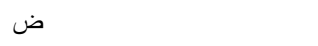 & $\mathrm{d}$ & voiced alveolar emphatic stop \\
\hline$b$ & $\mathrm{t}$ & voiceless dento-alveolar emphatic stop \\
\hline ظ & ð & voiced alveolar emphatic fricative \\
\hline$\varepsilon$ & $\varsigma$ & voiced pharyngeal fricative \\
\hline$\dot{\varepsilon}$ & $\gamma$ & voiced uvular fricative \\
\hline ف & $\mathrm{f}$ & voiceless labio-dental fricative \\
\hline 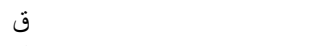 & $\mathrm{q} / \mathrm{g}$ & voiceless/voiced uvular stop \\
\hline ك & $\mathrm{k}$ & voiceless velar stop \\
\hline J & 1 & voiced alveolar lateral \\
\hline s & $\mathrm{m}$ & voiced bilabial nasal \\
\hline ن & $\mathrm{n}$ & voiced alveolar nasal \\
\hline 。 & $\mathrm{h}$ & voiceless glottal fricative \\
\hline g & $\mathrm{w}$ & voiced labio-velar glide \\
\hline ي & $\mathrm{y}$ & voiced palatal glide \\
\hline $1 \%$ & $\mathrm{a}$ & low short central unrounded \\
\hline íl & $\mathrm{u}$ & high short back rounded \\
\hline le & $\mathrm{i}$ & high short front unrounded \\
\hline$i$ & aa & low long central unrounded \\
\hline وو & $\mathrm{uu}$ & high long back rounded \\
\hline يب & ii & high long front unrounded \\
\hline 9 & o: & mid long back rounded \\
\hline او & aw & low short front unrounded + labio-velar glide \\
\hline اي & ay & low short front unrounded + palatal glide \\
\hline يبي & ee & mid long front unrounded \\
\hline
\end{tabular}

\section{Copyrights}

Copyright for this article is retained by the author, with first publication rights granted to the journal.

This is an open-access article distributed under the terms and conditions of the Creative Commons Attribution license (http://creativecommons.org/licenses/by/4.0/). 